\title{
Boko Haram Disgrace: Urgency for Renewal and Reform in northern Nigeria supported by the Muslim Leadership
}

\author{
Daud AbdulFattah Batchelor*
}

The infamous Boko Haram sect erupted on the world stage in 2009 with their aim to establish an Islamic State. Since its subsequent radicalisation resulting from heavy-handed treatment - including torture and murder - at the hands of state security forces, it now targets the army, police, and those associated with propagating western education. It has even degenerated into attacking the weakest participants, innocent civilians, especially school children. The most infamous act of Boko Haram was the abduction of nearly 300 female students in April 2014 from a government-run high school in the Christian town of Chibok. Over 70 percent of the girls were Christian, and reportedly a number were forcibly 'converted' to Islam. In February, 58 students mainly teenage boys, were burnt to death, shot or had their throats slit in a school attack. The mayhem continues as security forces seem incapable of containing the violence. 2050 people were killed in the first half of 2014 alone. The Paris Summit held in May led to a renewed military push from neighbouring countries with support from the United States, to contain Boko Haram. The Nigerian 'ulama have condemned Boko Haram's violence and language of arms as a fitna and cited it as "corruption on the earth" - one of the most serious crimes in Islam. ${ }^{1}$

Boko Haram's approach is however, aligned with certain influential opinionmakers in Muslim states who teach that receiving modern education is evil and forbidden. Such education is derisively dismissed as "western education" - synonymous with Christian missionaries and the detested former British colonialism, which subjugated the once-powerful Sokoto Muslim imamate. Demonisers of such education are often supervisors of traditional "Qur'anic schools," which follow a restricted non-contemporary syllabus. These are however, still the mainstay of the education system in the twelve northern 'Shariah-states.' A strong state-driven modern education system is essential, but a state program, which commenced in the 1970s floundered when oil prices fell abruptly. In the northeast and northwest Muslim zones, 50\% of children do not attend formal schooling compared with just $20 \%$ in southern Nigeria. Consequently, large segments of Muslims cannot participate effectively in Nigeria's development.

Boko Haram is another Saudi-Salafi-inspired militant group that split from its parent group and became radicalised. Its founder and spiritual head until his demise in 2009, Muhammad Yusuf, and some members were formerly with the Jama'at al-Izalat al-Bida'a group preaching for removal of religious innovations, 
but left to form the core of the "People of Sunnah for Preaching and Struggle". It became known colloquially as "Boko Haram" from its preaching platform that "participating in the western-style education system is prohibited." It believes that the western-style modern education system was a ploy by missionaries and colonialists to take over all aspects of Muslim life resulting in a Muslim "bit by bit becoming a disbeliever." The group is now committed to avenge from the suffering experienced due to injustice and atrocities committed upon them by the Nigerian Federal police in 2003 and 2009. Its subsequent actions however, decry any support for the values of the noble religion of Islam. In the heat of violent confrontation with government security forces, this commonly results in Islamically-unacceptable abuses within targeted groups. Consequently it commits criminal actions in the name of Islam which does great harm to its image. Islam as frequently emphasised by the Prophet (PBUH) strongly condemns the killing or kidnapping of innocent civilians. The kidnapped women are not spoils of any legitimate war and Islam prohibits forced conversions.

Its ideology involves calling certain Muslims as non-Muslims (takfir) whom it then justifies assassinating. Also, its leaders develop independent but often deviant rulings (ijtihad). Positions of the sect include that democracy totally conflicts with Islam, ruling by man-made laws is clear disbelief ( $k u f r)$, and employment for a government which does not rule by the Shari'ah is impermissible. Although claiming it does not intend harm to the general public, there are severe impacts on public interests - curfews and closures of markets, banks and educational institutions due to insufficient security. The common people live in fear as their homes can be subject at any time to army and police raids and residents with no links to the movement are at times dragged out and executed. The flight of investment from northern Nigeria acerbates the economic decline of the North vis-à-vis the South, and produces a scarcity of jobs.

Not surprisingly then in Nigeria, with limited education especially on health and nutrition, an estimated one million women and children die annually from largely preventable causes. Among children these are polio, malaria, measles, bacterial meningitis and malnutrition. This profile is typical of poor countries but if not for corruption, Nigeria should be wealthy from huge exports of 'sweet' oil worth 100 billion US dollars annually. Significantly, although Nigeria ranked fourth in 2012 amongst 27 Muslim countries in religiosity level of its Muslim citizens, in terms of social interaction indicators - especially how well the government nurtured weaker societal members such as women, infants and the poor - it ranked a lowly 47 out of 49 Muslim countries. ${ }^{2}$

Boko Haram who target schools because the latter teach a modern curriculum is clearly wrong. Islam strongly encourages the learning of beneficial knowledge whether revealed from the Qur'an and Sunnah (religious knowledge), or acquired 
from investigation of the material world (science and humanities). Prophet Muhammad (PBUH) stressed the obligation to acquire knowledge: "Search for knowledge is incumbent on every Muslim man and woman." Education for Muslims is not only to provide their frame of reference in Allah's creation, and knowledge of their fard obligations for worship, but also facilitates earning a living to contribute to society in a trade or profession. Scientific knowledge, even about public health or raising children, is essential for a robust society capable of developing Islamic civilisation. It will also help achieve essential objectives of Islamic law (maqāsid al-Sharī 'ah) - protection of life, progeny, intellect and wealth of citizens.

Abu Hamid al-Ghazali (d.1111 CE) considered essential knowledge as not confined to religious sciences but includes basic sciences. He stressed that this world is preparation for the Hereafter and when worldly affairs are managed well it facilitates one's success in the Ākhirah. He divided knowledge into fard 'ayn and fard kifäyah - the latter a collective obligation, which is discharged if some citizens pursue studies to provide community service, e.g. in medicine. Consequently, al-Ghazali favoured a mixed approach by bringing temporal knowledge within the ambience of fardh kifayah. Mohammad Hashim Kamali, CEO of the International Institute of Advanced Islamic Studies (IAIS) Malaysia, concluded in his book The Right to Education, Work and Welfare in Islam, that it is recommendable for the individual, and fard kifäyah on the whole community, to promote beneficial knowledge outside the sphere of religious sciences.

Hindrance to adoption of scientific knowledge in traditional Muslim religious schools is partly due to modern science having developed largely in the West, where textbooks are prepared and subjects taught from a secular perspective. This does not integrate well with religious education. Clearly, we must ascertain and articulate the spiritual link with science and encourage scientific inquiry and research. If only textbooks are available from secular sources, an introductory module should clarify key elements of the Islamic approach, placing subjects in the context of creation and its purpose and inculcating Islamic values and good behavior $(a k h l \bar{a} q)$.

In northern Nigeria there have been recent improvements with an expansion of urban Islamic public schools teaching a modified national curriculum which supports career development. The rise of Boko Haram is symptomatic of underlying factors in the body politic of the nation and the Muslims in particular. One characteristic of Nigerian Muslims is that they are a very much divided community. ${ }^{3}$ Credible leaders are needed to stand with a vision that actively seeks harmony between ethnic groups. It would seem essential that a fully representative council of the northern Shari'ah states meet to identify immediate and long-term measures for resolving festering social and religious 
problems. "Islamic" solutions may involve expanding modern education while not neglecting Islamic education, and enhancing unity between diverse Muslim groups - Salafis, Sufis and intellectuals; Hausas and minorities, madrasah and college staff and student fraternities. To help this process it is essential that a greater proportion of petrodollars are directed towards national development. A compact is needed with the Christian community to seek greater harmony and mutual respect. Muslims themselves are the key to the solution.

\section{Notes}

* Daud AbdulFattah Batchelor, an Australian scholar, is Associate Fellow at IAIS Malaysia. He has a broad experience in industry, academia and international consulting covering the fields of Environmental Management, Islamic Political Science and Earth Sciences. He has been active in Muslim community organisations and is co-founder of the Islamic College of Brisbane. Daud has an MA in Islamic and Other Civilisations from ISTAC, and was presented the Longmans Award for $\mathrm{PhD}$ research at Universiti Malaya. He has an MSc from the Imperial College of Science and Technology, London and a Master of Engineering Science. He is currently working at assisting the Afghanistan peace process by determining how differences may be resolved to achieve a workable political framework, in the context of his current research focus on Islamic political systems.

1. This crime draws the hadd punishment of "execution or crucifixion or the cutting-off of hands or feet from opposite sides, or exile from the land". (AlMa'idah 5:33).

2. Daud Batchelor, "New Islamic Index of Wellbeing for Rating Muslim Countries", Islamic and Civilisational Renewal, Vol. 4 No. 2, December 2012, 188-214.

3. Rafiu Ibrahim Adebayo, "Divisiveness among Muslims in Nigeria and its Implications for National Integration" Islamic and Civilisational Renewal, Vol. 5 No. 1, January 2014, 96-110. 